This Journal is available in Telkom University online Journals

Jurnal Manajemen Indonesia

Journal homepage: journals.telkomuniversity.ac.id/ijm

\title{
Value at Risk of Momentum Investment Strategy: Indonesia's Liquid Stocks Portfolio
}

\author{
A.Rowland Bismark Fernando Pasaribu
}

Gunadarma University: Economic Dept

\begin{abstract}
The capability of momentum investment strategy was explore through portfolio risk reduction by value at risk method at liquid shares in Indonesia stock exchange period 2008-2016. The purpose of this study are to analyse the value of momentum investment strategy risk reduction with the Value at Risk approach to historicalvolatility approach and examine differences in risk reduction performance by winner and loser portfolios formed from a collection of liquid shares in the Indonesia stock exchange for the pe riod 2008-2016. The stocks selection method in forming winners and losers portfolio done by Jegadesh and Titman procedure (1993) followed by calculation of risk reduction with the VaR-HisVol approach. The result show for quarterly and semester period winner portfolio has superior capacity of portfolio risk reduce than loser.
\end{abstract}

Keywords-Investment; Strategy; Portfolio, VaR.

\begin{abstract}
Abstrak
Kemampuan strategi investasi momentum dieksplorasi dalam teminologi pengurangan risiko portofolio dengan metode value at risk pada portofolio saham saham likuid di Bursa Efek Indonesia periode 2008-2016. Metode pemilihan saham pembentuk portofolio pemenang dan pecundang dilakukan dengan prosedur Jegadesh dan Titman (1993) dilanjutkan dengan kalkulasi pengurangan risiko dengan pendekatan VaR-His Vol. Hasil menunjukkan untuk portofolio pemenang periode triwulanan dan semester memiliki kapasitas superior mengurangi risiko portofolio daripada pecundang.
\end{abstract}

Kata kunci- Investasi, Strategi, Portofolio, VaR

\section{INTRODUCTION}

In general, risk is defined as the possibility of material or immaterial losses that may arise, directly or indirectly, affect the company's finances now and in the future. In everyday understanding that is generally known, there are two kinds of notions of risk, namely as a possibility of failure or failure to perform certain actions or actions; and risk as a possibility of loss that will be suffered or obtained due to certain actions or actions, even though the actions or actions themselves are successful. In the business world, it is theoretically known as an understanding that is used as a guideline, that a business that (will) provide high returns, must also have a high risk (high risk high return). Conversely, businesses that (will) provide low returns, generally also have a low risk. All understandings and limitations regarding the above risks relate the existence of risks to certain actions, actions, or business activities that will be carried out. In addition, risk has a broader understanding of the possibility of failure or loss in carrying out certain actions, actions or business activities. Risk, essentially attached to all things that exist in the existence of a person, an organization, institution, or business entity. Everything that is owned by a person or institution essentially contains risks, in the form of reduced value of wealth, increase in debt or liability. In the sense of accounting, anything that is on the asset or wealth side, and anything that is on the liability or liability side, as well as own or capital, all risk, all have the possibility of experiencing a change in value, which results in losses. Everything that is on the side of assets or

\section{Article info}

Received (19 ${ }^{\text {th }}$ September, 2018)

Revised (11 ${ }^{\text {th }}$ December, 2018)

Accepted (15 $5^{\text {th }}$ May, 2019)

Corresponding_author: rowland.pasaribu@gmail.com 
wealth (and capital), can be reduced in value. And everything on the liability or liability side and debt, can increase in number.

From the description above it can be concluded, that essentially risk can be interpreted as a possibility of loss that may be suffered on all sides of the existence of a person or an institution, at any time, either because of certain actions or actions and activities, or not. Thus, the presence of investors (both in retail and corporate terms) is always at risk at all times, always facing the possibility of loss, even if it is not doing certain activities.

Investing in a growing market for many people is considered more promising than established markets. Indonesia as a developing country (in line with the predicate of a developing capital market) with the worst investment climate in East Asia, in fact is still the destination country to invest for foreign investors. This is because they consider that by investing funds in developing countries, they can still explore business potentials that have not been fully explored, so that investors become very easy to get profits. In contrast to investments made in developed markets, it is difficult for investors to explore business potential that has been fully explored, making it difficult to make a profit in the market (Hameed dan Kusnadi, 2002).

Besides that, Indonesia is still the target of foreign investment, when viewed from the business life cycle approach; the Indonesian market enters as a growing category, which means that there is an attraction of high economic growth which is ultimately followed by a high rate of return. On the other hand, capital markets in developing countries have proven able to withstand the global crisis that occurred in 2008 compared to many developed countries. From the above explanation clearly illustrated the role of the capital market in incre asing economic growth so that the role of the capital market must be recognized as very important, especially in Indonesia.

In the world of investment, the term well-known stocks are known as winner-stock and bad-performing stocks known as loser-stocks. Another new term that emerges from the term winning and loser stocks is momentum. Momentum shows the tendency of stocks that have good performance (winning shares) will continue both in the future and stocks that have poor performance will continue to be bad in the future. The use of the word "momentum" gives rise to two notions based on Jegadeesh and Titman (1993); momentum as a risk proxy in the asset and momentum price valuation model as an investment strategy. Momentum as a risk proxy and as an investment strategy can be used to minimize uncertainty about the future in an investment activity, both uncertainty due to uneven information distribution or uncertainty due to risks that must be borne by an investor and can also be used for stock selection that should be owned to gain high returns (Kowanda and Pasaribu, 2012).

Future uncertainty and unequal information distribution are subjective conditions that dominate various concepts and approaches about investment strategies. Both practitioners and academics are still looking for formulations that are considered reliable regarding the relational level of return on investment and risk. There has been a lot of research on this subject, but no one has been convincing enough to produce a consensus. The investment strategy research topic itself generates many opportunities and challenges in terms of studies from the perspective of returns or risk of the portfolio itself. In Indonesia, the topic of a popular investment strategy research is the implementation of a momentum investment strategy that has lasted almost two decades (Sartono, 2000; Mardiyah, 2002; Nugroho, 2008; Hameed and Kusnadi, 2002; Sukmawati and Daniel, 2003; Rahmawati and Suryani, 2005; Indra, 2009; Najmudin, 2009; Wiksuana, 2009; Luxianto, 2010; Gunarsa and Ekayani, 2011; Hesti, 2011; Pasaribu, 2011; Suciningtias, 2011; Widiastuti, 2011; Kowanda and Pasaribu, 2012; Liem, 2012; Suarmanayasa and Susila, 2012; Loddy et.al, 2013; Swandewi and Mertha, 2013; Gleny and Tjong, 2014; Octavio and Lantara, 2014; Toro and Dewi, 2014; Maharani and Witiastuti, 2015; Ghofar and Aunilah, 2016; Isnawati, 2016; Julianti, 2016; Pramusinta and Arfianto, 2016; Pratama et al, 2016; Saputro and Badjra, 2016; and Sasmikadewi and Dewi, 2017). There's a lot methods in conducted in the previous research, still the discussion has not been optimal in terms of portfolio risk.

Although there has not been too much research regarding the risk of stock portfolios in Indonesia, in its development, there are positive indications of empirical studies that have been conducted, especially those using the Value at Risk approach. Some can be mentioned for example, Pasaribu's study (2010) which using it to measure the value of portfolio risk reduction formed by liquid stocks. This study was later developed by Juido and Pasaribu (2013) who tried to measure risk reduction of investment risk from a portfolio formed based on market capitalization. On the other hand, a study conducted by Fauzi (2013) attempts to discuss the risk of the issuer's stock portfolio with a historical-volatility VaR approach. The question then before reaching the estimation of portfolio risk value, what criteria implemented regarding the policy of stocks selecting that 
forming the portfolio. Answering this question, this research will adopt a momentum investment strategy (Kowanda and Pasaribu, 2012) concerning the stock selection policy of the winner-loser and the formingholding criteria for portfolio. Based on this description, the objectives of this research are: a) to analy ze the value of the momentum investment strategy risk reduction by using the Value at Risk technique of historicalvolatility approach at liquid stocks in the Indonesian stock exchange; b) examine the difference in the achievement of risk reduction by the winner-loser portfolio.

\section{LITERATUREREVIEW}

\section{A. Momentum Investment Strategy}

Momentum was first documented academically by Jegadeesh and Titman (1993). They examine the performance of US stock exchanges and find that strategies based on past returns can gain abnormal returns, which seems to imply that past returns may have some predictive power with respect to future profits and may conflict with an efficient market concept. More specifically, Jegadeesh and Titman (1993) found that portfolios that have passed the past as extreme winners and extreme losers in the short past are very profitable. In an efficient market, except for the systematic risk difference, the winner's portfolio must on average be the same as the loser's portfolio. Therefore, the resulting zero cost portfolio must produce zero average returns.

The definition of momentum portfolio, as defined by Jegadeesh and Titman (1993), remains largely unchanged to this day. Usually, there are various sub-strategies based on different lengths of formation and ownership periods. This sub-strategy is generally labeled as a J / K strategy, where each month the portfolio is formed based on individual stock returns over the past $\mathrm{J}$-month (where $\mathrm{J}$ equals 3, 6, 9 or 12 months), which is then owned for the next K-month (where K equals 3, 6, 9 or 12). Each monthly portfolio consists of a portfolio with the best performance minus the lowest portfolio, where the top and bottom portfolios are respectively the top and lowest deciles of each share in their J-month formation period. Jegadeesh and Titman (1993) found that the benefits of each strategy iteration were significantly positive during the period 1965-1989.

Further prove the elegance of momentum as "anomalies", Fama and French (1996) examine a set of anomalies (labeled because of their abnormal results on the CAPM) in the context of the three-factor model Fama and French (1993). They concluded that momentum is the only such anomaly (from being examined) which is largely unexplained by the three-factor model. After controlling for all three of these factors (market return, large-minus-small (size) and high low-minus ratio (book-to-market ratio)), the alpha monthly momentum strategy remains statistically and economically significant which may indicate a model-specifying error (in under the assumption of an efficient market). This led to the addition of a fourth factor in the three Fama-French factor models, namely the up-and-down momentum factor (UMD) - in Carhart (1997). Furthermore, Chan, Jegadeesh and Lakonishok (1996) examine evidence and determine that traditional risk factors do not explain the momentum. Instead, they argue that the results show that momentum is an inappropriate reaction to new information. However, they also found no evidence of a long-term reversal among stocks with high momentum. Although most momentum research centers are around the U.S. stock market, there is also substantial evidence that momentum seems to be international and not limited to U.S. markets or even in equity in this case.

\section{B. Momentum Prevalence}

Momentum in Europe has been well documented. Schiereck and Weber (1995) find evidence of momentum on the German market; while Bacmann and Dubois (2000) found it present in Switzerland. Rouwenhorst (1998) looks at stock returns in developed markets in Europe and documents evidence of momentum. Chui, Titman and Wei (2000) and Hameed and Kusnadi (2002) see momentum in Asia. Both find evidence of momentum; However, Chui, Titman and Wei found no evidence of momentum in Japan. In general, Chui, Titman and Wei found that momentum was weaker in Asia. Naughton, Troung and Veeraraghayan (2008) looked specifically at China and documented the momentum there but they found no relationship between trading volume and momentum returns as found in Lee and Swaminathan (2000). Alsubaie and Najand (2008) documented evidence of momentum on the Saudi Arabian stock market. Bacmann, Dubois and Isakov (2001) did not limit their studies to specific geographical locations and yet they examined the markets of G-7 countries, finding evidence of momentum in the seven countries.

Griffin, Ji and Martin (2003) tested the momentum in 40 countries around the world and found that yields of momentum were significant internationally. They also found that this momentum yield was not sig nificantly 
related to economic factors Chen, Roll and Ross (1986), and Chordia and Shivakumar (2002), which concluded that momentum, did not seem to be a compensation for macroeconomic risk. In addition, the yield of this momentum is positive during the business cycle (as opposed to the findings of Chordia and Shivakumar 2002).

Evidence of momentum in emerging markets is more diverse. Bekaert, Erb, Harvey and Viskanta (1997) state that their momentum findings are inconsistent, where the results seem to depend on the weighting method used to form a portfolio. However, Rouwenhorst (1999) found consistent momentum in a sample of 20 emerging markets. Bhojraj and Swaminathan (2001) also found strong momentum among emerging markets. Asness, Liew and Stevens (1997) find positive momentum to take a momentum strategy. Instead of sorting out individual stocks, he determines the ranking of the country index. The momentumportfolio is formed by buying the best performing indexes and selling the worst performing indexes. Chan, Hameed and Tong (2000) also see the momentum in the international equity market index. They found that momentum seemed to be stronger under the shorter holding period for the index and they also documented the relationship between the yields of momentum and trading volume from the previous period.

\section{Cross-sectional Determinants}

Given that the momentum was initially empirical evidence to look for a theory that contradicts the theory to seek empirical evidence, most research concentrates on describing the behavior of the anomaly. This study has found many transverse determinants that seem to be related to the phenomenon of momentum. Daniel and Titman (1999) report a negative relationship between the yield of momentum and the book-to-market ratio. They interpret this as evidence that momentum is stronger among emerging companies. Hong, Lim and Stein (2000) find that momentum strategies are negatively related to firm size. They also found that momentum was stronger in companies with lower analyst coverage. Lee and Swaminathan (2000) establish a relationship between the momentum and relative trading volume of a company. As a result, the momentum again seems stronger among companies that experience relatively higher trading volumes: the level of trading volume relative to their average trading volume.

There seems to be an ambiguous relationship between momentum and idiosyncratic volatility. Arena, Haggard and Yan (2008) found that the yield of momentum is positively related to idiosyncratic volatility. They also noted that the reversal of the previous momentum yield was also positively related to idiosyncratic volatility, where the reversal was greater and faster among companies with higher volatility. However, McLean (2010) found that momentum yields were not related to idiosyncratic volatility. Stivers and Sun (2010) found that the yield of momentum is negatively related to the dispersion of market returns, while Wang and Xu (2015) argue that lagging market volatility can predict future momentum again (negatively correlated). Antoniou, Doukas and Subrahmanyam (2010) find that investor sentiment is positively related to momentum. Chui, Titman and Wei (2000) claim that there is a positive relationship between "individualism" (the size of Hofstede, 2001) and the magnitude of the yield of momentum. Finally, Avramov, Cheng and Hameed (2013) claim that market liquidity predicts negative yields.

\section{Momentum Source}

Moskowitz and Grinblatt (1999) suggest that the real momentum is the momentum of the industry. The advantages of traditional momentum are largely explained by the momentum of the industry in the U.S. market: buying and selling stocks from industries that have won and lost from the past. However, Grundy and Martin (2001) find that industrial momentum is lost once there is a gap between the period of formation and holding, while traditional momentum remains. Chordia and Shivakumar (2002) also found that traditional momentum is separate from the industrial momentum in their macroeconomic factor model.

The Korajczyk and Sadka (2004) study investigates the theoretical impact of trade and transaction costs on momentum yield strategies and calculates the maximum capital investment that can be supported by investment momentum. Overall, their model shows that while transaction costs have a significant impact on overall profits; investment momentum can still remain profitable after transaction costs. In other words, transaction costs, as an effect of arbitrage restrictions, are not enough to fully explain the persistence of momentum anomalies. According to Kothari and Shanken (1992), portfolios that are formed on the basis of their past results will have a different burden on systematic factors that vary in time-variation. For example, in the case of momentum, buying and selling an extreme portfolio will also result in more extreme factor loading. In the case of positive (negative) factors during the formation period, it is expected that the winning portfolio tends to have a higher (lower) increase compared to the loser's portfolio. Therefore, the winning winner minus the loser portfolio is 
expected to have a positive (negative) factor loading, and therefore a positive (negative) result during the next holding period.

Grundy and Martin (2001) examine this line of reasoning in more detail. While they claim that the momentum strategy "guarantees the exposure of factors with varying time", they also claim that the exposure of these factors is not enough to fully explain the yield of momentum. Their findings indicate that the factor model (for example, the Fama-French three-model model) can only explain variations in the yield of momentum and not the magnitude. The momentum strategy, adjusted for yield factors (therefore, is only based on the component of the company's specific returns as defined by the three factor model), and then becomes profitable.

Chordia and Shivakumar (2002) present evidence that supports risk-based explanations, which shows that exposure to factors with time variations can drive momentum returns. They examine the yield of momentum relative to macroeconomic factors. They find that this can be explained by their macroeconomic factor model and that momentum investment is no longer profitable once the yield is adjusted to these lagging factors. Griffin, Ji and Martin (2003), on the other hand, did not find that macroeconomic explanations apply internationally (in non-US markets). Chordia and Shivakumar (2002) also examine the yield momentum for the historic business cycle and find that momentum is only beneficial during times of economic expansion (the yields are negative and insignificant during the recession). Based on their findings, momentum investment seems procyclical.

\section{E. Behavior-Based Theory}

Barberis, Shleifer and Vishny (1998) present a model of investor behavior that contains both under reaction and investor overreaction to new information. They combine two psychological concepts: conservatism and heuristic representatively. Conservatism causes investors to underreact during the short to medium term, while heuristics are representations that cause investors to overreact in the long run. Momentum is consequences of this underreact. Another interesting result of Barberis, Shleifer and Vishny (1998), which relates to momentum, is the long-term overreaction of investors due to the use of representation heuristics. Because investors observe a series of price increases (price decreases), they will wrongly conclude that this last price movement is representative of the trend and thus will raise prices up (down) further, beyond their fundamental value. This overreaction is finally corrected in the long run which leads to a long-term reversal. This is consistent, not only with the long-term reversal of DeBontd and Thaler (1985), but also with the long-term momentum of portfolio findings in Lee and Swaminathan (2000) and Jegadeesh and Titman (2001).

Daniel, Hirshleifer and Subramanyam (1998) also proposed a model that produces an overreaction; however, they use a different psychological basis from BSV. In Daniel, Hirshleifer and Subramanyam (1998), investors have a self-reliance bias which results in overconfidence. Individuals with self-attribution tend to associate positive results with their own abilities and negative outcomes for their environment, or luck. In this model, information traders experience self-reliance bias and as a result become too confident in their own stock selection capabilities. When they interpret news about stocks as a positive thing, their self-confidence that is too confident translates to being overly confident in this "winner" is to raise stock prices overreacting to the news. It is this overreaction that causes momentum and then this subsequent correction of overreaction causes the longterm reversal.

Grinblatt and Han (2005) argue that momentum is the result of prospect theory and mental calculations combined to create a disposition effect. Investors tend to hold back the losers of the past and sell the winners in the past, which causes under reaction of new information. This reluctance to sell past losers causes a delay in merging new information into prices, which causes under reaction. As information is slowly combined, prices continue to move, generating momentum, but not long-term reversals.

\section{F. Risk Based Theory}

Conrad and Kaul (1998) suggest that the profit momentum is only a buying a "high-return" and selling a "low-return" stocks, which results positive profit averagely. They outline the momentum yield to the components they consider to be a component of "time series predictability" and "cross -sectional variation" components and argue that the acquisition of momentum returns may be entirely due to cross-sectional variations in the average yield. The idea is that if stock returns follow a random path by following the flow, and even varying time changes in the flow are unpredictable, there will be no estimated time series; however, the momentum strategy can still produce positive returns because of cross-sectional dispersion. Past winners 
'portfolios tend to include more stocks with higher average yields, then compared to past losers' portfolios. Therefore, the momentum strategy will produce long positions that have higher unconditional average values relative to short positions, which in turn will produce positive returns from the combined portfolio. The empirical study of Conrad and Kaul shows that only the components of cross-sectional variation contribute positively to the yield of momentum.

His study Conrad and Kaul (1998) is intended only to present the possibility of cross -sectional variations that encourage momentum, not to prove it convincingly. They also do not make arguments for or against certain asset pricing models. Berk, Green and Naik (1999) base their model on the same premise as Conrad and Kaul (1998) (if one interprets unconditional mean values to represent returns to returns ): momentum is ultimately the results of a portfolio of winners who have returns expected results are greater than loser portfolios, ex ante. Their model concerns the optimal investment choice of the company, its effect on the company's systematic risk, and how changes in this risk can be predicted.

Berk, Green and Naik (1999) see companies as existing asset portfolios and growth options, where the company's systematic risk is the systematic risk of the portfolio. Existing assets are considered less risky than growth options. Just as companies run their choices (change those options into existing as sets), the increase in "existing assets" and their remaining choices decreases which causes a reduction in the overall weight of risky growth options (relative to existing assets), leading to a risk reduction systematic company as a whole. Systematic risk reduction (and future cash flows that have the potential to increase from increased growth choices) leads to an immediate rise in share prices, because equity investors now demand lower future profits in line with reduced risk. An immediate rise in the stock price is followed by a lower expected future yield, which results in a contrarian effect followed by a momentum effect because lower expected returns hold. Simulation results from their models are consistent with previous empirical work; however, contrarian sequences and momentum are the opposite of what we traditionally observe.

Another important contribution from Berk, Green and Naik (1999) is that their model provides a theoretical relationship between book value to market and market and observed returns patterns, through their investment decisions. The book-to-market ratio captures a mix of company assets relative to the overall asset base, while market value captures the weighting of assets in the mix of assets. Because book value to market (value) and market value (size) are factors in the popular three-factor Fama-French model, their model provides a theoretical foundation for the partial success of three factors in explaining momentum.

In Indonesia, the empirical study of the implementation of this momentum strategy crystallizes regarding the superiority of the performance of the portfolio of winners and losers. Those who stated that the performance of superior winning portfolio returns to the loser portfolio was a study conducted by Mardiyah (2002), Nugroho (2008), Najmudin (2009), Luxianto (2010), Hesti (2011), Pasaribu (2011), Suciningtias (2011 ), Widiastuti (2011), Kowanda and Pasaribu (2012), Liem (2012), Toro and Dewi (2014), Loddy et.al (2013), Julianti (2016), Pramusinta and Arfianto (2016) and Pratama et.al (2016). While those who contra (the performance of the superior losers portfolio against the winning portfolio) are Sartono (2000), Hameed and Kusnadi (2002), Sukmawati and Daniel (2003), Rahmawati and Suryani (2005), Indra (2009), Wiksuana (2009 ), Gunarsa and Ekayani (2011), Suarmanayasa and Susila (2012), Swandewi and Mertha (2013), Gleny and Tjong (2014), Octavio and Lantara (2014), Maharani and Witiastuti (2015), Ghofar and Aunilah (2016), Isnawati (2016), Saputro and Badjra (2016), Sasmikadewi and Dewi (2017).

\section{G. Value at Risk (VaR)}

The popular measure of risk is volatility; however the main problem with volatility is not taking into account the direction of investment movements: a stock may be very volatile because the price suddenly fluctuates up. For an investor, the risk is that the odds of losing money and Value at Risk are based on this. Assuming that investors are very concerned about odss big losses, then by using VaR, investors can determine their investment policies, both passive (VaR as a routine report), defensive (VaR is used for risk control tools) and active approaches, where reports VaR can be used to control risk and profit maximization such as capital allocation, investment funds, and so on.

VaR calculation uses the standard deviation of the yield. To calculate the VaR amount, three methods can be used (Crouchy, Galai, and Mart, 2001), namely: variance-covariance, historical simulation and Monte Carlo simulation. In this research variance-covariance method will be used in VaR calculations. 
The formula used for calculating risk using VaR is:

Scenario 1:

Individual VaR of shares $=1.65 \sigma \mathrm{x}$ Nominal value of investment

VaR Share Portfolio $=1.65 \times \sqrt{ } \mathrm{Xt} . \Sigma \mathrm{t}+1 . \mathrm{X} \mathrm{t}$

Scenario 2:

Individual VaR of shares $=2.33 \times \mathrm{x}$ Nominal value of investment

Share Portfolio VaR $=2.33 \times \sqrt{ } \mathrm{Xt} . \Sigma \mathrm{t}+1 . \mathrm{X} \mathrm{t}$

Where:

The magnitude of 1.65 is the $\alpha$ indicator of $5 \%$

The magnitude of 2.33 is an $\alpha$ indicator of $1 \%$

$\mathrm{Xt}$ is the amount of investment or nominal investment position

$+\mathrm{t}+1$ is an estimate of the variance-covariance matrix of stock returns in the portfolio

\section{H. Hypothesis Development}

By using the profit momentum approach Jegadesh and Titman (1993), it is assumed that Value at Risk The winning stock portfolio in the momentum investment strategy produces a greater risk reduce than the loser stock portfolio in other words the hypothesis has a winning stock portfolio of the past and sells losers' stock portfolios indeed profitable compared to the opposite.

\section{RESEARCH METHODOLOGY}

The populations in the study were all listed companies on the Indonesia Stock Exchange (IDX). While the Research samples are issuers those have been consistently listed in the LQ-45 index for the period 2008-2016. Determination of sample members in this study was carried out by purposive sampling method. Daily data of stock prices, daily stock trading frequency, and daily composite stock price index period (2008-2016) used for the classification of winners and losers stocks. Data obtained from internet (Reuters.com, YahooFinance.com) from criteria mentioned, there are 30 listed companies used as sample in this study.

\section{A. Operational Definitions Research Variables}

In order to process data, the following is a variable calculation procedure:
a. Market Return = Ln (IHSGt / IHSGt-1)
b. Stock Return = Ln (ISHit / ISHit-1)
c. Beta Stock $=R i=\alpha i+\beta i R M$
d. Variant of Stock Return $=\sigma \mathrm{i}^{2}=\beta \mathrm{i}^{2} . \sigma \mathrm{m}^{2}+\sigma e \mathrm{i}^{2}$
e. Stock Risk $=\sigma i=\sqrt{ } \sigma i^{2}$
f. Stock residual variance $=\sigma \mathrm{ei}^{2}=\mathrm{Ri}-\alpha \mathrm{i}-(\beta \mathrm{i} . \mathrm{Rm})$

\section{B. Analytical Techniques}

1. Share price data and composite stock price index in the daily period will be processed to produce actual return;

2. By using the market model, individual beta and residual variance will be calculated;

3. Estimating the variance-covariance matrix using beta and residual variance generated by stage 2 .

4. Rate daily returns from stocks that are included as samples in this study. 
5. Shares with the highest daily yield of $10 \%$ are categorized as winning shares and the lowest $10 \%$ yield is categorized as loser shares (Kowanda and Pasaribu, 2012). With the forming-holding period using a dynamic approach (the formation of the portfolio is carried out once the holding period is over), $3 \times 3$ (for quarterly), and 6x6 (for semester) formation.

6. The allocation of nominal investment value is carried out equally (equal weighted), where this step is needed for the VaR calculation value;

7. Comparison of the VaR of the stock portfolio of Winners and Losers;

\section{RESULT AND DISCUSSION}

Table 1. Descriptive Statistics

\begin{tabular}{lrrrr}
\hline & \multicolumn{1}{c}{ Min } & \multicolumn{1}{c}{ Max } & \multicolumn{1}{c}{ Average } & Std. Deviation \\
\hline RiW & $-1,437,176$ & $20,518,967$ & $4,145,391$ & $3,927,649$ \\
RiskPfW & $8,610,474$ & $210,000,000$ & $37,842,562$ & $45,686,101$ \\
RiskIndvW & $16,497,588$ & $247,000,000$ & $53,001,795$ & $49,926,390$ \\
ReduksiW & $4,047,747$ & $37,271,132$ & $15,337,852$ & $6,822,152$ \\
PersentaseW & $7.00 \%$ & $77.00 \%$ & $36.55 \%$ & 0.13927 \\
RiL & $-6,815,014$ & $5,875,776$ & $-1,710,586$ & $2,189,544$ \\
RiskPfL & $7,043,990$ & $58,438,159$ & $19,809,430$ & $11,619,029$ \\
RiskIndvL & $12,426,918$ & $76,475,484$ & $29,307,994$ & $15,337,900$ \\
ReduksiL & $-1,325,256$ & $21,855,696$ & $9,498,564$ & $5,135,661$ \\
PersentaseL & $-7.00 \%$ & $65.00 \%$ & $33.12 \%$ & 0.11267 \\
\hline
\end{tabular}

Source: Data Results

From table 1, seen that winner and loser portfolios produce negative minimum nominal returns, while for the winner's maximum nominal portfolio yield reaches Rp. 20,518,967 and losers only reach Rp. 5875.776 but when viewed from the average nominal return, the winner portfolio has an average of Rp. 4,145,391 while for the loser portfolio is negative Rp. 1,710,585. While the Nominal risk of the Winner portfolio shows an average higher value than the nominal risk of the loser portfolio, which is Rp. 37,842,562 and Rp. 19,809,429. For risk reduction, the average winner portfolio has a greater ability with a reduction rate of $36.55 \%$ while the loser portfolio is $33.12 \%$. For the loser portfolio, a minimum reduction of $-7 \%$ indicates that portfolio formation does not reduce the risk (fourth quarter 2014).

In table 2, we can see the development of the amount of VaR of individual stocks that form a portfolio of winners and losers (with the assumption, the allocation of investment funds in each portfolio forming stock is Rp. 100 million). From the calculation results it can be clarified that the share VaR forming the winning portfolio in general is indeed higher than the loser portfolio forming shares for the entire forming-holding period. But for each quarter and semester, the highest VaR value for the loser portfolio is always able to match the highest VaR value for the winning portfolio. For the first quarter, the highest VaR value occurred in 2014, which amounted to 44.52 million in the winning portfolio, while for the loser portfolio was able to reach the highest VaR of 52.14 million. In the second quarter, the highest number of shares VaR forming the winning portfolio was in 2011 with a value of 44.37 million, while in the loser portfolio, the highest VaR value was obtained in 2013 amounting to 57.28 million.

Table 2. Nominal Individual Value-at-Risk Portfolio (Rp. Million)

\begin{tabular}{cccccccccc}
\hline & $\mathbf{2 0 0 8}$ & $\mathbf{2 0 0 9}$ & $\mathbf{2 0 1 0}$ & $\mathbf{2 0 1 1}$ & $\mathbf{2 0 1 2}$ & $\mathbf{2 0 1 3}$ & $\mathbf{2 0 1 4}$ & $\mathbf{2 0 1 5}$ & $\mathbf{2 0 1 6}$ \\
\hline Winner & 44.52 & 27.00 & 36.21 & 25.64 & 43.26 & 35.95 & 15.20 & 20.85 & 26.88 \\
Loser & 17.23 & 18.78 & 21.18 & 52.14 & 31.11 & 30.21 & 12.88 & 12.43 & 15.93 \\
\hline
\end{tabular}




\begin{tabular}{|c|c|c|c|c|c|c|c|c|c|c|}
\hline \multirow{2}{*}{ Q2 } & Winner & 28.68 & 29.97 & 34.22 & 44.37 & 54.14 & 25.77 & 30.54 & 21.92 & 37.75 \\
\hline & Loser & 23.07 & 24.80 & 17.56 & 39.76 & 20.25 & 57.28 & 13.13 & 23.70 & 33.04 \\
\hline & Winner & 21.72 & 28.23 & 42.16 & 41.60 & 34.32 & 30.51 & 37.62 & 16.50 & \\
\hline & Loser & 18.32 & 19.64 & 28.22 & 48.48 & 26.23 & 34.31 & 24.78 & 23.60 & \\
\hline & Winner & 31.67 & 32.52 & 32.04 & 47.04 & 20.89 & 27.04 & 28.30 & 19.86 & \\
\hline & Loser & 26.13 & 18.95 & 18.95 & 76.48 & 28.74 & 19.74 & 18.17 & 71.69 & \\
\hline & Winner & 34.57 & 30.31 & 35.75 & 36.41 & 27.14 & 25.36 & 38.17 & 22.07 & 29.52 \\
\hline & Loser & 18.32 & 21.02 & 21.48 & 47.14 & 47.49 & 42.99 & 16.31 & 22.07 & 23.17 \\
\hline & Winner & 26.40 & 30.09 & 38.24 & 48.32 & 31.35 & 28.97 & 31.08 & 21.09 & \\
\hline & Loser & 26.13 & 15.56 & 22.65 & 65.34 & 27.10 & 21.11 & 24.55 & 55.08 & \\
\hline
\end{tabular}

Source: Data Results

A rather interesting condition occurred in 2012-2013, where in 2012 II quarter, the VaR value of the forming shares in the winning portfolio was 54.14 million decreased to 25.77 million in 2013 . The opposite was true in the stock forming the losers' portfolio that experienced an increase of nearly $300 \%$, which in 2012; the total VaR value was 20.25 million increasing to 57.28 million in 2013 .

Table 3. Value-at-Risk of Winner-Loser Portfolio (Rp. Million)

\begin{tabular}{llllllllll}
\hline & $\mathbf{2 0 0 8}$ & $\mathbf{2 0 0 9}$ & $\mathbf{2 0 1 0}$ & $\mathbf{2 0 1 1}$ & $\mathbf{2 0 1 2}$ & $\mathbf{2 0 1 3}$ & $\mathbf{2 0 1 4}$ & $\mathbf{2 0 1 5}$ & $\mathbf{2 0 1 6}$ \\
\hline Winner & 30.42 & 11.72 & 22.34 & 18.60 & 24.86 & 16.58 & $\mathbf{1 3 . 4 9}$ & 9.90 & 11.80 \\
Loser & 15.01 & 11.72 & 12.68 & 33.89 & 19.64 & 22.04 & 8.64 & 7.04 & 11.80 \\
\hline Winner & 16.59 & 20.32 & 15.61 & 29.69 & 38.24 & 17.28 & 11.78 & 12.88 & 21.28 \\
Loser & 17.68 & 20.32 & 10.34 & 24.21 & 12.94 & 35.43 & 8.64 & 18.97 & 21.83 \\
\hline Winner & 17.68 & 12.17 & 29.48 & 27.76 & 17.79 & 15.58 & 8.64 & 8.61 & \\
Loser & 10.69 & 12.17 & 19.51 & 31.24 & 18.48 & 17.42 & 8.64 & 13.21 & \\
\hline Winner & 16.61 & 20.96 & 20.90 & 37.44 & 13.87 & 16.37 & 19.50 & 9.95 & \\
Loser & 16.17 & 10.98 & 10.84 & 56.60 & 21.21 & 11.10 & 19.50 & 58.44 & \\
\hline Winner & 20.13 & 21.66 & 17.00 & 24.11 & 16.63 & 13.94 & 25.96 & 12.90 & 16.08 \\
Loser & 10.69 & 15.76 & 12.75 & 28.30 & 30.09 & 26.55 & 10.26 & 15.25 & 12.93 \\
\hline Winner & 19.45 & 14.90 & 25.31 & 29.28 & 16.91 & 14.92 & 22.85 & 10.16 & \\
Loser & 16.17 & 9.55 & 15.89 & 48.01 & 18.43 & 12.33 & 21.29 & 41.87 & \\
\hline
\end{tabular}

\section{Source: Data Results}

The result of portfolio formation-VaR (both winner and loser portfolios) for forming-holding (hereinafter abbreviated as $\mathrm{FH}$ ) $3 \times 3$ and $6 \times 6$ during the study period can be seen in table 3 . While the calculation of risk reduction in the top three periods is presented in table 4 where the $\mathrm{FH}$ period in first quarter aggregately average reduction achievement for winner portfolio was $41.14 \%$ while loser was $32.42 \%$. Reductions that are considered large enough in the winner portfolio FH in the first quarter occurred in year 2009, 2013, 2015 and 2016 which reached a risk reduction value of more than 50\%; 2009 (56.59\%), $2010(53.87 \%), 2012(52.49 \%)$ and 2013 $(56.1 \%)$. For loser portfolio, the achievement of risk reduction that was considered quite large occurred in year $2010(37.58 \%)$ and $2015(43.32 \%)$.

For Q2-FH I, aggregately the average achievement of winner portfolio risk reduction is still superior $(41.16 \%)$ when compared to loser portfolio $(31.56 \%)$. In Q2-FH, the winner's portfolio highest reduction achievement was in 2010 (54.38\%), 2014 (61.42\%), 2015 (41.24\%) and 2016 (43.63\%) while for loser portfolio the biggest risk reduction period was in 2010 which reached more than $40 \%$ quarterly. Furthermore at Q3-FH period aggregately average achievement of the risk reduction in winner's portfolio again still superior (45.09\%) to the loser portfolio $(41.82 \%)$. The high reduction achievement in the winner portfolio for Q3-FH period 
occurred in 2009 (56.87\%), $2012(48.15 \%), 2013(48.94 \%) 2014(77.05 \%), 2015(47.81 \%)$ which turned out to be highest reduction value of all quarterly, mid-yearly FH periods. While at loser portfolio, the same reduction in portfolio risk for the Q3-FH period was in 2008 (41.63\%), $2013(49.76 \%)$ and $2014(65.16 \%)$ and 2015 $(44.06 \%)$. And in the Q4-FH period, aggregately the average achievement of the risk reduction in the winner's portfolio again still superior (37.79\%) compared to loser portfolio (28.77.9\%). Highest reduction value in winner portfolio achieved 2008 (47.55), 2009 (45.58\%) and 2015 (49.89\%). While on same time, on loser portfolio occurred in 2009 (42.08\%), 2010 (42.81\%) and 2013 (43.76\%).

Table 4. Winner and Loser Portfolio Risk Reduction

\begin{tabular}{|c|c|c|c|c|c|c|c|c|c|c|c|c|}
\hline & \multicolumn{2}{|c|}{ Q1 } & \multicolumn{2}{|c|}{ Q2 } & \multicolumn{2}{|c|}{ Q3 } & \multicolumn{2}{|c|}{ Q4 } & \multicolumn{2}{|c|}{ Mid-1 } & \multicolumn{2}{|c|}{ Mid-2 } \\
\hline & Winner & Loser & Winner & Loser & Winner & Loser & Winner & Loser & Winner & Loser & Winner & Loser \\
\hline 2007 & $31.68 \%$ & $12.90 \%$ & $42.14 \%$ & $23.37 \%$ & $18.63 \%$ & $41.63 \%$ & $47.55 \%$ & $38.13 \%$ & $41.76 \%$ & $41.63 \%$ & $26.35 \%$ & $38.13 \%$ \\
\hline 2008 & $56.59 \%$ & $37.58 \%$ & $32.20 \%$ & $18.05 \%$ & $56.87 \%$ & $38.01 \%$ & $15.06 \%$ & $42.08 \%$ & $28.54 \%$ & $25.00 \%$ & $50.50 \%$ & $38.61 \%$ \\
\hline 2009 & $38.31 \%$ & $40.15 \%$ & $54.38 \%$ & $41.11 \%$ & $30.09 \%$ & $30.85 \%$ & $34.76 \%$ & $42.81 \%$ & $52.45 \%$ & $40.67 \%$ & $33.81 \%$ & $29.83 \%$ \\
\hline 2010 & $27.45 \%$ & $35.00 \%$ & $33.10 \%$ & $39.11 \%$ & $33.19 \%$ & $35.56 \%$ & $20.41 \%$ & $25.99 \%$ & $33.78 \%$ & $39.97 \%$ & $39.39 \%$ & $26.53 \%$ \\
\hline 2012 & $42.53 \%$ & $36.89 \%$ & $29.37 \%$ & $36.09 \%$ & $58.15 \%$ & $29.56 \%$ & $33.58 \%$ & $26.21 \%$ & $38.74 \%$ & $36.64 \%$ & $46.07 \%$ & $32.01 \%$ \\
\hline 2013 & $53.87 \%$ & $27.03 \%$ & $32.94 \%$ & $38.15 \%$ & $48.94 \%$ & $49.23 \%$ & $39.46 \%$ & $43.76 \%$ & $45.02 \%$ & $38.25 \%$ & $48.51 \%$ & $41.58 \%$ \\
\hline 2014 & $11.25 \%$ & $32.94 \%$ & $61.42 \%$ & $34.25 \%$ & $77.05 \%$ & $65.15 \%$ & $31.11 \%$ & $-7.29 \%$ & $31.97 \%$ & $37.12 \%$ & $26.53 \%$ & $13.27 \%$ \\
\hline 2015 & $52.49 \%$ & $43.32 \%$ & $41.24 \%$ & $19.97 \%$ & $47.81 \%$ & $44.06 \%$ & $49.89 \%$ & $18.48 \%$ & $41.52 \%$ & $30.89 \%$ & $51.83 \%$ & $23.98 \%$ \\
\hline 2016 & $56.11 \%$ & $25.95 \%$ & $43.63 \%$ & $33.94 \%$ & & & & & $45.53 \%$ & $44.18 \%$ & & \\
\hline Avg & $41.14 \%$ & $32.42 \%$ & $41.16 \%$ & $31.56 \%$ & $45.09 \%$ & $41.82 \%$ & $37.79 \%$ & $28.77 \%$ & $39.92 \%$ & $37.15 \%$ & $40.37 \%$ & $30.49 \%$ \\
\hline
\end{tabular}

Source: Data Results

For $6 \times 6$ FH periods in the first and second semesters, the average achievement of the winner's stock portfolio risk was still superior compared to the loser portfolio as in the $3 \times 3 \mathrm{FH}$ period, where the average risk reduction achievement in the first semester for winner portfolio (39.92\%) and loser portfolio (37.15\%) and second semester for winner portfolio $(40.37 \%)$ and loser portfolio (30.49\%). Reduction achievements that were considered high enough in the first semester for winner portfolio occurred in 2008 (41.76\%), 2010 (52.45\%), 2013 (45.02\%), 2015 (41.52\%) and 2016 (45.53\%). While the high achievement in reducing the portfolio risk of the same FH period for the loser portfolio was in 2008 (41.63\%), 2010 (40.67\%), and $2016(44.18 \%)$. For the 6x6 FH period of the second semester, the achievement of reduction which was quite high in the winner portfolio occurred in 2008 (50.50\%), 2012 (46.07\%), $2013(48.51 \%)$ and 2014 (51.83). While the same reduction in portfolio risk for the FH period for the loser portfolio was in 2013 (41.58\%), So aggregately the results of the risk reduction achievement with the formation of a portfolio of both winner and loser portfolios during the 2008-2016 observation period both in the $3 \times 3$ and $6 \times 6$ FH periods it can be concluded that winner portfolio risk reduction is always superior compared to the reduction risk of loser portfolios.

\section{A. Mean-Different Results}

From the results of hypothesis testing (table 5 panel A) for forming a quarterly period, some of the hypothesis test results state that the difference in rates of return that occur between the portfolio of winners and losers is different and statistically significant. From table 5 it can be seen that for the period of the first quarter of 2008quarter III 2009, the difference in the rate of return of the winning portfolios against the loser portfolio was statistically significant. The superiority of the winning portfolio returns continues in the first, second and fourth quarter of 2010. In 2011, a significant difference occurred for the first quarter, and II. For 2012-2013, except for the second quarter 2012 and IV quarter 2013 formations, the difference between the two portfolios was statistically significant with a difference in the range of $0.87 \%-1.6 \%$ per day. While in the 2014-2015 period, significant differences only occurred in the forming period of the second quarter of 2014, the first quarter and the third quarter of 2015. For 2016, up to the second quarter forming period, the difference in returns in both portfolios was statistically significant. The differences that occur at the yield level are not always statistically significant, there are several forming periods that state this, for example the fourth quarter of 2009. Although there is a difference of $4.28 \%$ per day between the return on portfolio winners and losers, it is not significant 
statistically. The second highest difference occurred in the second quarter of 2015 , where despite differences in the yields of both portfolios up to $3.92 \%$ per day, the difference was not statistically significant.

Table 5. Panel A. Mean-Different Test Results - Quarterly Forming

\begin{tabular}{cccccc}
\hline Period & Sig.t & Mean-Diff & Period & Sig.t & Mean-Diff \\
\hline 2008Q1 & 0.024 & $1.14 \%$ & 2012Q2 & 0.012 & $1.60 \%$ \\
2008Q2 & 0.013 & $0.86 \%$ & 2012Q3 & 0.034 & $0.87 \%$ \\
2008Q3 & 0.017 & $1.14 \%$ & 2012Q4 & 0.011 & $1.02 \%$ \\
2008Q4 & 0.019 & $0.82 \%$ & 2013Q1 & 0.001 & $1.42 \%$ \\
2009Q1 & 0.009 & $0.76 \%$ & 2013Q2 & 0.009 & $1.61 \%$ \\
2009Q2 & 0.033 & $0.97 \%$ & 2013Q3 & 0.010 & $0.97 \%$ \\
2009Q3 & 0.001 & $1.02 \%$ & 2013Q4 & 0.247 & $0.36 \%$ \\
2009Q4 & 0.211 & $4.28 \%$ & 2014Q1 & 0.148 & $2.06 \%$ \\
2010Q1 & 0.001 & $1.35 \%$ & 2014Q2 & 0.000 & $1.15 \%$ \\
2010Q2 & 0.001 & $1.01 \%$ & 2014Q3 & 0.075 & $1.01 \%$ \\
2010Q3 & 0.065 & $1.03 \%$ & 2014Q4 & 0.220 & $0.38 \%$ \\
2010Q4 & 0.001 & $1.30 \%$ & 2015Q1 & 0.003 & $0.58 \%$ \\
2011Q1 & 0.020 & $1.50 \%$ & 2015Q2 & 0.197 & $3.92 \%$ \\
2011Q2 & 0.005 & $1.71 \%$ & 2015Q3 & 0.006 & $0.66 \%$ \\
2011Q3 & 0.309 & $1.37 \%$ & 2015Q4 & 0.054 & $2.90 \%$ \\
2011Q4 & 0.189 & $1.47 \%$ & 2016Q1 & 0.000 & $1.00 \%$ \\
2012Q1 & 0.035 & $1.07 \%$ & 2016Q2 & 0.009 & $1.22 \%$ \\
\hline S0urC: Dat & & & & \\
\hline
\end{tabular}

Source: Data Results

From the table it can be seen that for the period of the first quarter of 2008-quarter III 2009, the difference in the rate of return of the winning portfolios against the loser portfolio was statistically significant. The superiority of the winning portfolio returns continues in the first, second and fourth quarter of 2010. In 2011, a significant difference occurred for the first quarter, and II. For 2012-2013, except for the second quarter 2012 and IV quarter 2013 formations, the difference between the two portfolios was statistically significant with a difference in the range of $0.87 \%-1.6 \%$ per day. While in the $2014-2015$ period, significant differences only occurred in the forming period of the second quarter of 2014, the first quarter and the third quarter of 2015. For 2016, up to the second quarter forming period, the difference in returns in both portfolios was statistically significant. The differences that occur at the yield level are not always statistically significant, there are several forming pe riods that state this, for example the fourth quarter of 2009. Although there is a difference of $4.28 \%$ per day between the return on portfolio winners and losers, it is not significant statistically. The second highest difference occurred in the second quarter of 2015 , where despite differences in the yields of both portfolios up to $3.92 \%$ per day, the difference was not statistically significant.

In Panel B, you can see in full the significant differences in returns on both portfolios for semester forming periods. In general, except for the five forming periods (Mid II 2009, Mid II 2013, Mid I \& II 2014, and Mid II 2015), all differences that occur are statistically significant with the range of differences occurring is $0.7 \%-1$, $1.8 \%$ per day. Based on these facts, it can be said that in terms of both portfolio returns, both in quarterly and semester forming periods, the winning portfolio is superior to the loser portfolio. The comparative results of Value at Risk for both portfolios can be seen in Table 5 Panel C. Simultaneously it can be said that for quarterly and semester forming, the value at Risk of the winning portfolio is lower than the risk of the loser portfolio. For quarterly forming periods, the average portfolio risk difference reaches $3.4 \%$ per day while for the semester risk of forming a portfolio it reaches $4 \%$ per day. 
Table 5 Panel B. Mean-Different Test Results - Mid-Forming

\begin{tabular}{ccc|ccc}
\hline Period & Sig.t & Mean-Diff & Period & Sig.t & Mean-Diff \\
\hline 2009-Mid.1 & 0.013 & $0.71 \%$ & 2013-Mid.1 & 0.019 & $0.77 \%$ \\
2009-Mid.2 & 0.329 & $1.31 \%$ & 2013-Mid.2 & 0.187 & $0.28 \%$ \\
2010-Mid.1 & 0.001 & $0.89 \%$ & 2014-Mid.1 & 0.059 & $1.38 \%$ \\
2010-Mid.2 & 0.009 & $0.88 \%$ & 2014-Mid2 & 0.083 & $0.59 \%$ \\
2011-Mid.1 & 0.001 & $1.37 \%$ & 2015-Mid.1 & 0.18 & $2.03 \%$ \\
2011-Mid.2 & 0.044 & $1.80 \%$ & 2015-Mid.2 & 0.049 & $1.50 \%$ \\
2012-Mid.1 & 0.004 & $1.11 \%$ & 2016-Mid.1 & 0.000 & $0.84 \%$ \\
2012-Mid.2 & 0.008 & $0.75 \%$ & & & \\
\hline Source: Data
\end{tabular}

Source: Data Results

Table 5 Panel C. Mean-Difference of Value at Risk

\begin{tabular}{ccc}
\hline Period & Sig.t & Mean-Diff \\
\hline VaR- Quarterly & 0.046 & $3.41 \%$ \\
VaR-Semesterly & 0.037 & $4.17 \%$
\end{tabular}

Source: Data Results

Adagium of an investment (whatever the instrument and media) that has become a global consensus are returns and risks. From the results of empirical calculations, a confirmation obtained that objectively the winner portfolio risk is indeed superior to the loser portfolio. Superior here refers to the amount of reduction achieved by both portfolios. On average, for quarterly forming periods, the winner portfolio has the capacity to reduce risk with a range of $30-41.5 \%$ per day, while the loser portfolio ranges from $28 \%-38.7 \%$. In the semester period the winner portfolio remained superior regarding risk reduction with a range of $30.9 \%-36.5 \%$, where the loser portfolio was only $30.5 \%-37.15 \%$. Conceptually, the results of this study support the research of Mardiyah (2002), Nugroho (2008), Najmudin (2009), Luxianto (2010), Hesti (2011), Pasaribu (2011), Suciningtias (2011), Widiastuti (2011), Kowanda and Pasaribu (2012), Liem (2012), Toro and Dewi (2014), Loddy et al (2013), Julianti (2016), Pramusinta and Arfianto (2016) and Pratama et.al (2016) which stated that the implementation of momentum strategies indeed more profitable. However, the difference between these researches is more in terms of reducing portfolio risk. In terms of risk reduction, generally this study also supports Pasaribu (2010), also Juido and Pasaribu (2013), that portfolio diversification indeed reduce the risk level of individual stocks.

Why momentum investing works even through value at risk method? One of the reasons, momentum is so widely misunderstood is because not enough advocates of the strategy have explained it well enough (although maybe that's on purpose). It's also counter-intuitive to almost every other strategy out there, which can make investors uncomfortable if they don't know what they're doing. Even if you aren't a practicing value investor, the value anomaly is easy to explain - buy at a discount and then wait. The momentum factor is based on buy high, sell higher or alternatively, cut your losses and let your winners run. Momentum investing is based on that gap in time that exists before mean reversion occurs and usually seen in the short-to intermediate-term.

Another misunderstanding comes from the fact that investors are constantly told that it's a huge mistake to chase performance. And it is a terrible idea to chase performance if you don't know what you're doing or why you're doing it. Momentum is chasing performance, but in a systematic way, with an entry and exit strategy in place. Momentum tries to take advantage of performance chasers who are making emotional decision $\mathrm{s}$. This is why the best momentum investors use a rules-based approach, to avoid those emotions. So what exactly is momentum? In short, momentum is the fact that markets tends to continue to trend in the direction they're going much longer than most people assume is possible. Investments that have performed well tend to continue to perform well and investments that have performed poorly tend to continue to perform poorly. And this research justified it by risk reduction capability of momentum investment strategy through value at risk method. 


\section{CONCLUSION}

This study aims to analyze the value of momentum investment strategy risk reduction with the Value at Risk approach to historical-volatility approach and examine differences in risk reduction performance by winner and loser portfolios formed from a collection of liquid shares in the Indonesia stock exchange for the period 20082016. The selection of Portfolio Winner and Loser forming stocks adopts Jegadeesh and Titman (1993) momentum investment strategy. From the calculation results, it is obtained the results that on average, for the quarterly forming period, the winner portfolio has the capacity to reduce risk in the range of $38-45 \%$ per day, while the loser portfolio ranges from $29 \%-42 \%$. In the semester period, the winning portfolio remained superior regarding risk reduction with a range of $39.92 \%-40.4 \%$, where the loser portfolio was only $30.5 \%-37.15 \%$. The results of the statistical test also stated that the winning portfolio risk is indeed lower than the risk of the loser portfolio. For quarterly forming periods, the average portfolio risk difference reaches $3.4 \%$ per day while for the semester risk of forming a portfolio it reaches $4 \%$ per day. In other words, the momentum investment strategy can be used as an investment strategy for stock investors at Indonesia stock exchange because it has a superior risk-reducing performance. For further research can expand the period of the forming-holding portfolio and VaR technique approach used and increase the scope of the research sample.

\section{REFERENCES}

Alsubaie, A., \& Najand, M. (2008). Trading Volume, Price Momentum, and the 52-Week High Price Momentum Strategy in the Saudi Stock Market. Available at SSRN.

Antoniou, C., Doukas, J. A., \& Subrahmanyam, A. (2010). Sentiment and momentum. Journal of Financial and Quantitative Analysis, Forthcoming.

Arena, M. P., Haggard, K. S., \& Yan, X. (2008). Price momentum and idiosyncratic volatility. Financial Review, 43(2), 159-190.

Asness, C. S., Liew, J. M., \& Stevens, R. L. (1997). Parallels between the cross-sectional predictability of stock and country returns. Journal of Portfolio Management, 23(3), 79.

Avramov, D., Cheng, S., \& Hameed, A. (2013). Time-varying momentum payoffs and illiquidity. Available at SSRN.

Bacmann, J. F., \& Dubois, M. (2000). La performance des stratégies contraires et momentum sur le marché suis se. Financial Markets and Portfolio Management, 14(4), 252-266.

Bacmann, J. F., Dubois, M., \& Isakov, D. (2001). Industries, business cycle and profitability of momentum strategies: An international perspective. In EFMA 2001 Lugano Meetings.

Barberis, N., Shleifer, A., \& Vishny, R. (1998). A model of investor sentiment. Journal of financial economics, 49(3), 307-343.

Bekaert, G., Erb, C. B., Harvey, C. R., \& Viskanta, T. E. (1997). What matters for emerging equity market investments. Emerging markets quarterly, 1(2), 17-46.

Berk, J. B., Green, R. C., \& Naik, V. (1999). Optimal investment, growth options, and security returns. The Journal of Finance, 54(5), 1553-1607.

Bhojraj, S., \& Swaminathan, B. (2001). Macromomentum: Evidence of predictability in international equity markets. Available at SSRN 273569.

Carhart, M. M. (1997). On persistence in mutual fund performance. The Journal of finance, 52(1), 57-82.

Chan, K., Hameed, A., \& Tong, W. (2000). Profitability of momentum stragegies in the international equity markets. Journal of financial and quantitative analysis, 35(2), 153-172.

Chan, L. K., Jegadeesh, N., \& Lakonishok, J. (1996). Momentum strategies. The Journal of Finance, 51(5), 1681-1713.

Chen, N. F., Roll, R., \& Ross, S. A. (1986). Economic forces and the stock market. Journal of business, 383403.

Chordia, T., \& Shivakumar, L. (2002). Momentum, business cycle, and time-varying expected returns. The Journal of Finance, 57(2), 985-1019. 
Chui, A. C., Wei, K. C., \& Titman, S. (2000). Momentum, legal systems and ownership structure: An analysis of Asian stock markets. Sheridan, Momentum, Legal Systems and Ownership Structure: An Analysis of Asian Stock Markets (December 2000).

Conrad, J., \& Kaul, G. (1998). An anatomy of trading strategies. The Review of Financial Studies, 11(3), 489519.

Crouchy, M., Galai, D., \& Mark, R. (2001). Risk Management. McGraw Hill.

Daniel, K., Hirshleifer, D., \& Subrahmanyam, A. (1998). Investor psychology and security market under-and overreactions. the Journal of Finance, 53(6), 1839-1885.

Daniel, K., \& Titman, S. (1999). Market efficiency in an irrational world. Financial Analysts Journal, 55(6), 2840.

De Bondt, W. F., \& Thaler, R. (1985). Does the stock market overreact?. The Journal of finance, 40(3), 793805.

Dimson, E., Marsh, P., \& Staunton, M. (2008, March). 108 years of momentum profits. In EFA 2008 Athens Meetings Paper.

Fama, E. F., \& French, K. R. (1993). Common risk factors in the returns on stocks and bonds. Journal of financial economics, 33(1), 3-56.

Fama, E. F., \& French, K. R. (1996). Multifactor explanations of asset pricing anomalies. The journal of finance, 51(1), 55-84.

Fauzi, A. (2013). Analis is Risiko Portfolio dengan Metode Value at Risk (VaR) melalui pendekatan Historical Method (Back Simulation)”. Working Paper, Universitas Negeri Sunan Kalijaga.

Ghofar, A., \& Aunilah, R. A. (2016). The Influence of Accrual Anomaly and Winner-Loser Anomaly on Abnormal Return: The Indonesian Evidence. DLSU Business \& Economics Review, 26(1).

Gleny, G., \& Tjong, W. (2014). Pengaruh Sstrategi value, size dan momentum terhadap excess return di Indonesia. Jurnal Sosial Humaniora, 7(2), 172-188.

Griffin, J. M., Ji, X., \& Martin, J. S. (2003). Momentum investing and business cycle risk: Evidence from pole to pole. The Journal of Finance, 58(6), 2515-2547.

Grinblatt, M., \& Han, B. (2005). Prospect theory, mental accounting, and momentum. Journal of financial economics, 78(2), 311-339.

Grundy, B. D., \& Martin, J. S. M. (2001). Understanding the nature of the risks and the source of the rewards to momentum investing. The Review of Financial Studies, 14(1), 29-78.

Gunarsa, \& Ekayani, S. (2011). Pengujian Eksistensi Anomali Winner-Loser Saham Industri Manufaktur di Bursa Efek Indonesia. Jurnal Ilmiah Manajemen \& Akuntansi STIE Triatma Mulya, 16(2), 34-40.

Hameed, A., \& Kusnadi, Y. (2002). Momentum strategies: Evidence from Pacific Basin stock markets. Journal of financial research, 25(3), 383-397.

Hesti, W. (2011). Efisiensi Pasar dan Behafioral Finance. Jurnal Akuntansi dan Keuangan, 3(1), 82-87.

Hofstede, G. (2001). Culture's consequences: Comparing values, behaviors, institutions and organizations across nations. Sage publications.

Hong, H., Lim, T., \& Stein, J. C. (2000). Bad news travels slowly: Size, analyst coverage, and the profitability of momentum strategies. The Journal of Finance, 55(1), 265-295.

Indra, P. (2009). Analisis Market Overreaction yang Ditandai dengan Pembalikan Harga Jangka Pendek pada Saham-Saham yang Diperdagangkan di Bursa Efek Indonesia.” Jurnal Ekonomi dan Bisnis.

Isnawati, E. (2016). Analisis Overreaction terhadap Harga Saham Manufaktur Yang Terdaftar Di BEI. Jurnal Ilmu dan Riset Akuntansi,4(11).

Jegadeesh, N., \& Titman, S. (1993). Returns to buying winners and selling losers: Implications for stock market efficiency. The Journal of finance, 48(1), 65-91.

Jegadeesh, N., \& Titman, S. (2001). Profitability of momentum strategies: An evaluation of alternative explanations. The Journal of finance, 56(2), 699-720.

Johnson, T. C. (2002). Rational momentum effects. The Journal of Finance, 57(2), 585-608. 
Juido, K., \& Pasaribu, R. B. F. (2013). Value At Risk Portofolio Saham Likuid: Kapitalisasi Besar dan Kapitalisasi Kecil (Studi Kasus Saham Lq-45 di Bei Januari 2011-Desember 2012). Prosiding PESAT, 5.

Julianti, M. (2016). Pola Return Portofolio Winner-loser di Bursa Efek Indonesia. Jurnal Terapan Manajemen dan Bisnis, 2(2), 57-67.

Korajczyk, R. A., \& Sadka, R. (2004). Are momentum profits robust to trading costs?. The Journal of Finance, 59(3), 1039-1082.

Kothari, S. P., \& Shanken, J. (1992). Stock return variation and expected dividends: A time-series and crosssectional analys is. Journal of Financial Economics, 31(2), 177-210.

Kowanda, D., \& Pasaribu, R. B. F. (2012). Strategi Investasi Momentum: Profit Momentum Portofolio Pemenang-Pecundang di Indonesia (Momentum Investment Strategy: The Portofolio Momentum Profit Winner-Losers in Indonesia). Jurnal Ekonomi dan Bisnis, 6(2), 109-136.

Lee, C. M., \& Swaminathan, B. (2000). Price momentum and trading volume. the Journal of Finance, 55(5), 2017-2069.

Liem, R. W. (2012). Momentum Investing Strategy in Idx: An Experiment. Journal of Applied Finance and Accounting, 5(1), 71-109.

Loddy, L. P., Murhadi, W. R., \& Putu Anom, M. (2013). Strategi Aktif dan Strategi Pasif Pada Pembentukan Portofolio Periode 2 Januari 2012 - 28 Desember 2012. Jurnal Manajemen Teori dan Terapan, 6(2), 119-125.

Luxianto, R. (2010). Comparison in Measuring Effectiveness of Momentum and Contrarian Trading Strategy in Indonesian Stock Exchange. Available at SSRN 1680228.

Maharani, S., \& Witiastuti, R. S. (2015). Fenomena Market Overreaction di Bursa Efek Indonesia. Management Analysis Journal,4(1), 30-38.

Mardiyah, A. A. (2002). The Effect of Profitability of Momentum Strategies and Volume on Future Returns: an Empirical Evidence From Jakarta Stock Exchange and Kualalumpur Stock Exchange. Journal of Indonesian Economy and Business, 17(4), 440-459.

McLean, R. D. (2010). Idiosyncratic risk, long-term reversal, and momentum. Journal of Financial and Quantitative Analysis, 45(4), 883-906.

Moskowitz, T. J., \& Grinblatt, M. (1999). Do industries explain momentum?. The Journal of finance, 54(4), 1249-1290.

Najmudin, N. (2009). Eksistensi Profitabilitas Strategi InvestasiMomentum Di BEI. Performance, 9(2), 1-20.

Naughton, T., Truong, C., \& Veeraraghavan, M. (2008). Momentum strategies and stock returns: Chinese evidence. Pacific-Basin Finance Journal, 16(4), 476-492.

Nugroho, B. Y. (2008). Profitabilitas Strategi Momentum Di Bursa Efek Indonesia (Periode Januari 2003Desember 2007). Jurnal Fakultas Hukum UII, 12(3), 175-186.

Octavio, D. Q., \& Lantara, I. W. N. (2014). Market Overreaction, Size Effect, atau Liquidity Effect? Studi Pada Bursa Efek Indonesia. Jurnal Manajemen Strategis Bisnis dan Kewirausahaan, 8(1), 11-17.

Pasaribu, R. B. (2010). Value at risk-portfolio: Dan likuiditas saham. Jurnal Akuntansi dan Manajemen, 21(2), 105-127.

Pasaribu, R. B. F. (2011). Anomali Overreaction di Bursa Efek Indonesia: Penelitian Saham LQ 45. Jurnal Ekonomi dan Bisnis, 5(20), 87-115.

Pramusinta, W. S., \& Arfianto, E. D. (2016). Analisis Pengaruh Distress Risk, Size, Book to Market, dan Momentum terhadap Return Saham (Studi Pada Perusahaan Sektor Industri Dasar dan Industri Barang Konsumsi periode 2009-2014). Diponegoro Journal of Management, 5(1), 427-441.

Pratama, I. G. S., Purbawangsa, I. B. A., \& Artini, L. G. S. (2016). Analisis Overreaction Pasar Pada Saham Winner dan Loser di Bursa Efek Indonesia. E-Jurnal Ekonomi dan Bisnis Universitas Udayana, 5, 43874414.

Rahmawati, S. T., \& Suryani, T. (2005). Over reaksi pasar terhadap harga saham perusahaan manufaktur di Bursa Efek Jakarta. Simposium Nasional Akuntansi 8-Solo, 64-74.

Rouwenhorst, K. G. (1998). International momentum strategies. The journal of finance, 53(1), 267-284. 
Rouwenhorst, K. G. (1999). Local return factors and turnover in emerging stock markets. The journal of finance, 54(4), 1439-1464.

Saputro, N. R., and Badjra, B. I. 2016. "Kinerja Portofolio Saham Berdasarkan Strategi Investasi Momentum Pada Industri Manufaktur.” E-Jurnal Manajemen Unud, 5(1): 2016: 623-649.

Saputro, R. N., \& Badjra, I. B. (2016). Kinerja Portofolio Saham Berdasarkan Strategi Investasi Momentum pada Industri Manufaktur. E-Jurnal Manajemen Universitas Udayana,5(1).

Sartono, A. (2000). Overreaction of The Indonesian Capital Market: Is Market Rational?. Gadjah Mada International Journal of Business, 2(2), 163-184.

Sasmikadewi, A. I. A., \& Dewi, M. R. (2017). Perbandingan Kinerja Portofolio Saham Winner-Loser Berdasarkan Strategi Investasi Momentum. E-Jurnal Manajemen Unud, 6(2), 857-888.

Schiereck, D., \& Weber, M. (1995). Zyklische und antizyklische Handelsstrategien am deutschen Aktienmarkt(No. 35478). Darmstadt Technical University, Department of Business Administration, Economics and Law, Institute for Business Studies (BWL).

Stivers, C., \& Sun, L. (2010). Cross-sectional return dispersion and time variation in value and momentum premiums. Journal of Financial and Quantitative Analysis, 45(4), 987-1014.

Suarmanayasa, I. N., \& Susila, G. P. A. J. (2012). Eksistensi Anomali Winner-Loser Saham Industri Di Pasar Modal Indonesia. JINAH (Jurnal Ilmiah Akuntansi dan Humanika), 2(1).

Suciningtias, S. A., \& SE, M. (2011). Gejala Overreaction pada Saham-saham yang tergabung dalam Jakarta Islamic Index Di Bursa Efek Jakarta. Jurnal Ekonomi \& Bisnis, 12(1), 58-76.

Sukmawati, \& Daniel, H. (2003). Overreact Hipothesis dan Price Earnings Ratio Anomaly Saham-Saham Sektor Manufaktur di Bursa Efek Jakarta. Jurnal Riset Ekonomi dan Manajemen, 3(1).

Swandewi, G. A. E., \& Mertha, I. M. (2013). Abnormal Return Portofolio Winner-Loser Saham Manufaktur di PT. Bursa Efek Indonesia. E-Jurnal Akuntansi, 85-99.

Toro, M. J. S., \& Dewi, T. A. C. (2014). The investigation of the profitability of momentum strategy implementation in Islamic stocks in Indonesia. South East Asia Journal of Contemporary Business, Economics and Law, 5(1), 51-55.

Wang, K. Q., \& Xu, J. (2015). Market volatility and momentum. Journal of Empirical Finance, 30, 79-91.

Widiastuti, E. (2011). Short Contrarian Investment Strategy: Pengujian Winner-Loser Anomaly Pada SahamSaham Di Bursa Efek Indonesia. Performance, 14(2).

Wiksuana, I. G. B. (2009). Kinerja Portofolio Saham Berdasarkan Strategi Investasi Momentum di Pas ar Modal Indonesia. Jurnal Manajemen dan Kewirausahaan, 11(1), 73-84. 